Available online at http://jddtonline.info

RESEARCH ARTICLE

\title{
STUDY OF THE EVALUATION OF MUTAGENIC EFFECTS OF ANTIMALARIAL DRUG CHLOROQUINE IN AMES SALMONELLA ASSAY
}

\author{
Rakesh kumar, Laxmi Banjare * \\ Department of Pharmaceutical chemistry,Shri Rawatpura Sarkar Institute of Pharmacy, Kumhari(C.G.), India- 490042 \\ *Corresponding Author's Email: banjarelaxmi24@gmail.com
}

\begin{abstract}
:
Antimalarial drugs are frequently administered to people in tropical regions of the world. It is known that commonly used antimalarial drug Chloroquine binds strongly to deoxyribonucleic acid (DNA). In the present study the mutagenic effects of antimalarial drug Chloroquine was evaluated in the Ames Salmonella assay. CHQ is the most commonly used antimalarial drug at present in different parts of the world. After the malaria parasite Plasmodium falciparum started to develop widespread resistance to $\mathrm{CHQ}$, new potential utilizations of this cheap and widely available drug have been investigated. CHQ has been extensively used in mass drug administration's which may have contributed to the emergence and spread of resistance. As it mildly suppresses the immune system, it is used in some autoimmune disorders, such as rheumatoid arthritis. CHQ is in clinical trials as an investigational antiretroviral in humans with HIV-1/AIDS The results of the mutagenicity assay indicate that chloroquine is a weak mutagen in Salmonella strain TA100. CHQ showed a very weak mutagenic effect in the absence of S9 mix in strain TA100. But this compound didn't show any mutagenic effect on TA98 strain both in presence or absence of S9 mix. This observation suggests that metabolic products of CHQ might not play a significant role in induction of mutation. Keywords: Chloroquine, Ames Salmonella assay, mutagenic effect
\end{abstract}

\section{INTRODUCTION:}

Malaria is a mosquito-borne infectious disease caused by eukaryotic protist of the genus Plasmodium. It is widespread in tropical and subtropical regions, including parts of the Asia, Americas and Africa. Each year, there are approximately 350-500 million cases of malaria, killing between one and three million people, the majority of whom are young children. Several drugs are used for the treatment of malaria. Use of prophylactic drugs is seldom practical for full-time residents of malaria-endemic areas, and their use is usually restricted to short-term visitors and travelers to malarial regions. This is due to the cost of purchasing the drugs, negative side effects from long-term use, and because some effective anti-malarial drugs are difficult to obtain outside of wealthy nations. Quinine was used starting in the 17th century as a prophylactic against malaria. The development of more effective alternatives such as chloroquine, primaquine and quinacrine in the 20th century reduced the reliance on quinine. Today, quinine is still used to treat chloroquine resistant Plasmodium falciparum, as well as severe and cerebral stages of malaria, but is not generally used for prophylaxis. Chemically the antimalarial drugs are classified as Aryl amino alcohols (Quinine, quinidine, mefloquine, halofantrine), 4-aminoquinolines (Chloroquine, amodiaquine), Folate synthesis inhibitors (sulphones, sulphonamides, proguanil, chloroproguanil, diaminopyrimidine like pyrimethamine) and 8aminoquinolines (Primaquine, WR238, 605) etc. The mechanism of action of CHQ is unclear. Being alkaline, the drug reaches high concentration within the food vacuoles of the parasite and raises its $\mathrm{pH}^{11}$. CHQ inhibits the parasitic enzyme heme polymerase that converts the toxic heme into non-toxic hemazoin, thereby resulting in the accumulation of toxic heme within the parasite. Other mechanisms suggested include formation of drug-heme complex and intercalation of the drug with the parasitic DNA $^{12,13}$.Almost $90 \%$ of the administered CHQ is absorbed from gut and rapidly absorbed from intra muscular and subcutaneous sites. It has a large distribution volume due to extensive sequestration in tissues of liver, spleen, kidney, lung etc. Hence a larger loading dose is generally required. Therapeutic blood levels persist for 610 days and elimination half-life is 1-2 months. Half of the drug is excreted unchanged by the kidneys, remaining is converted to active metabolites in the liver. Dose - Oral$10 \mathrm{mg} / \mathrm{kg}$ stat., then three doses of $5 \mathrm{mg} / \mathrm{kg}$, over $36-48$ hours.It has been found that $\mathrm{CHQ}$ have some adverse effects upon administration. It can cause dizziness, headache, diplopia, disturbed visual accommodation, nausea, malaise, and pruritus of palms, soles and scalp. $\mathrm{CHQ}$ can also cause visual hallucinations, confusion, and occasionally frank psychosis. When used as prophylactic at $300 \mathrm{mg}$ of the base/ week, it can cause retinal toxicity after 3-6 years (i.e. after 50-100 g of CHQ). Intra muscular injections of CHQ can cause hypotension and cardiac arrest, particularly in children. CHQ forms intercalated complexes with DNA and acts as an inhibitor of DNA synthesis and repai It is deposited in tissues and can cross the placenta. CHQ is also reported to induce teratogenic effects in rats .Mutations are changes in the DNA sequence of a cell's genome and are caused by radiation, viruses, transposons, errors that occur during meiosis or DNA replication and various chemicals. They can also be induced by the organism itself, by cellular processes such as hypermutation. Mutation can result in several different types of change in DNA sequences; these can either have no effect or alter the product of a gene that prevents the gene from functioning properly or completely. If a mutation changes a protein produced by a gene, this will probably be harmful, with about 70 percent of these 
mutations having damaging effects, and the remainder being either neutral or weakly beneficial. Due to the damaging effects that mutations can have on cells, organisms have evolved mechanisms such as DNA repair to remove mutations.A laboratory test developed by biochemist Bruce N. Ames to determine the possible carcinogenic nature of a substance. The Ames test involves using a particular strain of the bacteria Salmonella typhimurium that lacks the ability to synthesize histidine and is therefore very sensitive to mutation. The bacteria are inoculated into a medium deficient in histidine but containing the test compound. If the compound results in DNA damage with subsequent mutations, some of the bacteria will regain the ability to synthesize histidine and will proliferate to form colonies. The culture is evaluated on the basis of the number of mutated bacterial colonies it produced. The ability to replicate mutated colonies leads to the classification of a substance as probably carcinogenic. Since the standard tests for carcinogenicity done on rodents take years to complete and are expensive to do. The procedure is described in a series of papers from the early 1970s by Bruce Ames and his group at the University of California, Berkeley.

The test uses several strains of the bacterium Salmonella typhimurium that carry mutations in genes involved in histidine synthesis, so that they require histidine for growth. For mutagenicity assays, Salmonella strains TA97a, TA98, TA100 and TA102 are usually used. Each tester strain contains a different type of mutation in histidine operon. In addition to the histidine mutation the standard tester strains contain other mutations that greatly enhance their ability to detect mutagens. One mutation (rfa) causes partial loss of the lipopolysaccharide barrier coating the surface of the bacteria and increases permeability to large molecules such as benzo [a] pyrene that do not penetrate the normal cell wall. The other mutation uvrB is a deletion of a gene coding for the DNA excision repair system, resulting in greatly increased sensitivity in detecting many mutagens ${ }^{1}$. The standard tester strains TA97a, TA98, TA100, TA102 contain Rfactor plasmid, pKM101. These four strains were used since they were recommended for the routine mutagenicity and antimutagenicity assay of different drugs and chemicals $^{7}$ TA97a and TA98 detect frame shift mutagens TA100 detects base pair mutagens. Maron and Ames (1983) primarily recommended both TA98 and TA100 for routine mutagenicity assay. TA102 contains A-T base pairs at site of the mutation (determined by DNA sequence analysis) in contrast to the other Salmonella tester strains that detect mutagens damaging the G-C base pair. In this tester strain the mutation has been introduced into a multicopy plasmid as a result around 30 copies of the mutant gene exist for back mutation ${ }^{7}$.

Some chemicals (called pro-mutagens) are not mutagenic unless metabolized to more active derivatives. Liver enzymes that normally detoxify harmful metabolic intermediates are often responsible for the activation of pro-mutagens into mutagens. For example, benzo (a) pyrene is not mutgenic but it is converted by liver enzymes to diolepoxides which are potent mutagens and carcinogens. Therefore, to test for such pro-mutagens, an extract of rat liver enzymes is included in the reversion assay.

In both toxicity and mutation tests, tester strains are combined with S9 mix or buffer, test or control article, a trace of histidine or tryptophan and molten agar. The bacteria use the trace histidine or tryptophan to undergo several cell divisions, but will stop growing once they have run out, leaving a characteristic "background lawn" that decreases in density with increasing toxicity. After 48 hours, only those cells that have undergone a reverse mutation turning the essential gene back on have survived, producing mutant colonies. The background lawn density is scored followed by counting the number of revertant colonies. Mutation results are reported as revertants per plate.

\section{METHOD:}

\section{Animals}

Charles River male rats of 150-175 g. were used for the preparation of liver homogenate (S9) for bacterial antimutagenicity assays. They were kept four per cage with husk bedding. Animals were received from the animal house of our institute and were fed balanced rodent pellet diet (Gold Mohar, Lipton Ltd., Chandigarh, India) and water ad libitum. The environment had a controlled $12 \mathrm{~h}$ light and $12 \mathrm{~h}$ dark cycle. Ambient temperature and relative humidity were $22^{\circ} \pm 2^{\circ} \mathrm{C}$ and $55 \% \pm 5 \%$ respectively.

\section{Chemicals}

Chloroquine phosphate was purchased from the local market. Biotin, histidine, ampicillin trihydrate, sodium azide (SA), 4-nitro-o-phenylenediamine (NPD), were supplied from Sigma Chemical Company (St. Louis, MO); agar and nutrient broth were supplied from HiMedia laboratories Ltd (India). Magnesium sulfate, magnesium chloride, potassium chloride, citric acid monohydrate, dibasic potassium phosphate, sodium ammonium phosphate, sodium hydroxide, glucose were purchased from E. Merck Limited (Mumbai, India).

\section{Bacterial Strains}

For mutagenicity assays, Salmonella strains TA98 and TA100 were used. Each tester strain contains a different type of mutation in histidine operon. In addition to the histidine mutation the standard tester strains contain other mutations that greatly enhance their ability to detect mutagens. One mutation (rfa) causes partial loss of the lipopolysaccharide barrier coating the surface of the bacteria and increases permeability to large molecules such as benzo pyrene that do not penetrate the normal cell wall. The other mutation uvrB is a deletion of a gene coding for the DNA excision repair system, resulting in greatly increased sensitivity in detecting many mutagens. The standard tester strains TA98 and TA100 contain R-factor plasmid, pKM101. TA98 detect frame shift mutagens while TA100 detects base pair mutagens ${ }^{7}$.primarily recommended both TA98 and TA100 for routine mutagenicity assay. 
Composition of the Media and Solutions used

\section{Vogel-Bonner medium E (50X)}

For 1 litre medium

\section{Ingredient}

Warm distilled $\mathrm{H}_{2} \mathrm{O}\left(45^{\circ} \mathrm{C}\right)$

Magnesium sulfate $\left(\mathrm{MgSO}_{4}, 7 \mathrm{H}_{2} \mathrm{O}\right)$

Citric acid monohydrate

Potassium phosphate, dibasic (anhydrous) $\left(\mathrm{K}_{2} \mathrm{HPO}_{4}\right)$

Sodium ammonium phosphate $\left(\mathrm{NaHNH}_{4} \mathrm{PO}_{4}, 4 \mathrm{H}_{2} \mathrm{O}\right)$
Per liter
$670 \mathrm{ml}$
$10 \mathrm{~g}$
$100 \mathrm{~g}$
$500 \mathrm{~g}$
$175 \mathrm{~g}$

The salts were added in the order indicated in the warm water and each salt was allowed to dissolve completely before adding the next. Volume was adjusted to 1 liter and then autoclaved before use for $20 \mathrm{~min}$.

\section{5 mM hitidine/biotin solution:}

$\begin{array}{ll}\text { Ingredient } & \text { Per 250 liter } \\ \text { D-Biotin } & 30.9 \mathrm{mg} \\ \text { L-Histidine. } \mathrm{HCl} & 24.0 \mathrm{mg} \\ \text { Distilled } \mathrm{H}_{2} \mathrm{O} & 250 \mathrm{ml}\end{array}$

The solution was sterilized by passing through $0.22-\mu \mathrm{m}-\mathrm{membrane}$ filter.

Top agar

$\begin{array}{ll}\text { Ingredient } & \text { Per 250 liter } \\ \text { Agar } & 6 \mathrm{~g} \\ \mathrm{NaCl} & 5 \mathrm{~g} \\ \text { Distilled } \mathrm{H}_{2} \mathrm{O} & 100 \mathrm{ml}\end{array}$

After dissolving thoroughly the agar was autoclaved for $20 \mathrm{~min}$.

Salt solution (1.65 M KCl + 0.4 M MgCl2) for S9 mix

Ingredient

Potassium chloride $(\mathrm{KCl})$

Magnesium chloride $\left(\mathrm{MgCl}_{2}, 6 \mathrm{H}_{2} \mathrm{O}\right)$

Distilled $\mathrm{H}_{2} \mathrm{O}$
Per 500 liter

$61.5 \mathrm{~g}$

$40.7 \mathrm{~g}$

to final volume of $500 \mathrm{ml}$

The solution was autoclaved for $20 \mathrm{~min}$.

0.2 M sodium phosphate buffer, $\mathrm{pH} 7.4$ for $\mathrm{S} 9$ mix

Ingredient

$0.2 \mathrm{M}$ sodium dihydrogen phosphate

$\left(\mathrm{NaH}_{2} \mathrm{PO} 4, \mathrm{H}_{2} \mathrm{O}\right)(13.8 . \mathrm{g} / 500 \mathrm{ml})$

$0.2 \mathrm{M}$ disodium hydrogen phosphate

$\left(\mathrm{Na}_{2} \mathrm{HPO}\right)(14.2 \mathrm{~g} / 500 \mathrm{ml})$

\section{Per 500 ml}

$60 \mathrm{ml}$

$400 \mathrm{ml}$

The solution was sterilized by autoclaving.

0.1 M NADP solution (nicotine adenine dinucleotide phosphate) for S9 mix

$\begin{array}{ll}\text { Ingredient } & \text { Per } \mathbf{5} \text { ml } \\ \text { NADP } & 383 \mathrm{mg}\end{array}$

Sterile distilled $\mathrm{H}_{2} \mathrm{O} \quad 5 \mathrm{ml}$ 
1 M glucose-6-phosphate for S9 mix

$\begin{array}{ll}\text { Ingredient } & \text { Per } \mathbf{1 0 ~ m l} \\ \text { Glucose-6-phosphate (G-6-P) } & 2.82 \mathrm{~g} \\ \text { Sterile distilled } \mathrm{H}_{2} \mathrm{O} & 10 \mathrm{ml}\end{array}$

This solution was stored in freezer.

S9 mix (rat liver microsomal enzymes + cofactors)

Ingredient

Rat liver S9 (Phenobarbitol induced)

$\mathrm{MgCl}_{2}-\mathrm{KCl}$ salts

1 M glucose-6-phosphate

0.1 M NADP

$0.2 \mathrm{M}$ phosphate buffer, $\mathrm{pH} 7.4$

Sterile distilled $\mathrm{H}_{2} \mathrm{O}$

\section{Per $50 \mathrm{ml}$ of S9 mix}

$2 \mathrm{ml}$

$1 \mathrm{ml}$

$0.25 \mathrm{ml}$

$2 \mathrm{ml}$

$25 \mathrm{ml}$

$16.75 \mathrm{ml}$

The solution was prepared fresh and kept in ice.

\section{Ampicillin solution $(8 \mathrm{mg} / \mathrm{ml})$}

Ingredient

Ampicillin trihydrate

Sodium hydroxide $(0.02 \mathrm{~N})$

\section{Per 100 ml}

$0.8 \mathrm{~g}$

$100 \mathrm{ml}$

The solution was sterilized by passing through $0.22-\mu \mathrm{m}-\mathrm{membrane}$ filter.

\section{Minimal glucose plate}

Ingredient

Agar

Distilled $\mathrm{H}_{2} \mathrm{O}$

$50 \mathrm{X}$ VB salts

$40 \%$ glucose

\section{Per 1000 ml}

$15 \mathrm{~g}$

930ml

$20 \mathrm{ml}$

$50 \mathrm{ml}$

$15 \mathrm{gm}$ of agar was added to $930 \mathrm{ml}$ of distilled $\mathrm{H}_{2} \mathrm{O}$ and autoclaved for $20 \mathrm{~min}$. when the solution has cooled slightly, 20 $\mathrm{ml}$ of sterile VB salts and $50 \mathrm{ml}$ of $40 \%$ glucose were added. After addition of all the ingredients the solution should be stirred thoroughly then was poured $30 \mathrm{ml}$ of it into each petri plate. The 50X VB and $40 \%$ glucose were autoclaved separately.

\section{Ampicillin plates and ampicillin/tetracycline plates (for master plates)}

For the tests for ampicillin/tetracycline resistance

Ingredient

Agar

Distilled $\mathrm{H}_{2} \mathrm{O}$

$50 X$ VB salts

$40 \%$ glucose

Sterile histidine $\mathrm{HCl}, \mathrm{H}_{2} \mathrm{O}$

(2 g per $400 \mathrm{ml} \mathrm{H}_{2} \mathrm{O}$ )

Sterile $0.5 \mathrm{mM}$ biotin

Sterile ampicillin solution

$(8 \mathrm{mg} / \mathrm{ml} 0.02 \mathrm{~N} \mathrm{NaOH})$

\section{Per $1000 \mathrm{ml}$}

$15 \mathrm{gm}$

$910 \mathrm{ml}$

$20 \mathrm{ml}$

$50 \mathrm{ml}$

$10 \mathrm{ml}$

$6 \mathrm{ml}$

$3.15 \mathrm{ml}$

Sterile tetracycline solution

$3.15 \mathrm{ml}$

$(8 \mathrm{mg} / \mathrm{ml} 0.02 \mathrm{~N} \mathrm{NaOH})$ 
Agar was autoclaved for water for $20 \mathrm{~min}$. Glucose, 50X VB salts and histidine to the hot solution then mixed and cooled to approximately $50^{\circ} \mathrm{C}$. Tetracyclin was added only for the strain TA102 which is tetracycline resistant. 50X VB salts and $40 \%$ glucose solutions were sterilized separately by autoclaving for $20 \mathrm{~min}$. Histidine and biotin solutions was sterilized by filtration. Plates to be used for tests of tetracycline and /or ampicillin resistance can be stored for approx. 2 months at $4{ }^{\circ} \mathrm{C}$.

\section{Preparation of S9 Fraction}

The procedure of Ames et al. and Garner et al. were used for the preparation of rat liver homogenate (S9) ${ }^{5}$ Charles river male rats of $150-175 \mathrm{~g}$ were fed $0.1 \%$ phenobarbital in their drinking water for seven days. On day 6 , no foods were provided for these rats. The next day, they were killed for the rat liver homogenate (S9). All steps of this preparation were performed at $0^{\circ} \mathrm{C}$ to $4^{\circ} \mathrm{C}$ with cold and sterile solutions and glassware. The livers (10-15 gm each) were washed in an equal volume of $0.15 \mathrm{M} \mathrm{KCl}(3 \mathrm{ml} / \mathrm{gm}$ of wet liver) and homogenized with a homogenizer. The homogenate was centrifuged for 10 minutes at $9000 \mathrm{~g}$ and the supernatant that is called as S9 fractions were distributed in $2 \mathrm{ml}$ aliquots in small sterile plastic tubes, quickly frozen and stored at $-80^{\circ} \mathrm{C}$. The $\mathrm{S} 9 \mathrm{mix}$ was prepared following the method of Maron and Ames.

\section{Bacterial Mutagenicity assay:}

Standard mutagenicity assay tests were performed on TA98 and TA 100 strains $^{5}$. The test drug CHQ was dissolved in distilled water and its different concentrations $(10,100,500,1000 \mu \mathrm{g} /$ plate $)$ were used in mutagenicity assay. In the assay, $0.1 \mathrm{ml} /$ plate of the different concentrations of CHQ (i.e. $0.1 \mathrm{ml}$ containing 10, 100, 500 and $1000 \mu \mathrm{g} / \mathrm{plate})$ were used. The plates were inverted within $1 \mathrm{~h}$ and placed in a dark vented incubator at $37^{\circ} \mathrm{C}$ for 48 h. Similar experiments were carried out for positive mutagens (4-nitro-o-phenylenediamine for TA98 and SA for TA100) and negative control in absence of S9 mix. Four plates were used for each concentration tested and for both positive and negative controls. After $48 \mathrm{~h}$ of incubation, the revertant colonies on the test plates were counted. The presence of the background lawn on all the plates was confirmed. A similar experiment was also carried out using liver homogenate (S9) fractions. Positive mutagens 2-AF was used for TA98 experiments with S9 mix. Due to shortage of time similar experiment with TA100 was not been able to carry out. The spontaneous reversion rates of these two different Salmonella strains were checked and were similar as reported earlier.

\section{Statistical Analysis}

The results of all the mutagenicity assays were analysed using Dunnett's multiple comparison ${ }^{4}$ with solvent treated control. The level of significance is given in the respective tables.

\section{RESULT:}

Table 1 and Table 2 are summaries of the results of the Ames mutagenicity assay in salmonella typhimurium strains TA100 and TA98 after CHQ treatment. A significant increase in revertant colonies was observed at the doses $100 \mu \mathrm{g} /$ plate to $1000 \mu \mathrm{g} /$ plate in the salmonella strain TA100 when compared to solvent treated control. At $5000 \mu \mathrm{g} /$ plate a significant decrease in the revertant colonies indicate that the CHQ was toxic at this dose. The results of solvent treated control and positive control are at per the values reported by other authors. No significant revertant colonies were observed in any of the concentration tested in case of salmonella strain TA98 either with or without $\mathrm{S} 9$ activation. So this result shows that the CHQ was not mutagenic in salmonella strain TA98. This overall results indicate that the CHQ is a weakly mutagenic in salmonella strain TA100 which detect the base pair substitution mutants. The number of revertant colonies of strain TA100 and TA98 were significantly decreased at $5000 \mu \mathrm{g} /$ plate dose when compared to solvent treated control. This observation suggests that at this dose the drug CHQ shows toxic effects in both the strains.

Table 1: Number of revertants induced by chloroquine in salmonella plate incorporation test using TA 100

\begin{tabular}{lc}
\hline $\begin{array}{l}\text { Chemicals } \\
(\boldsymbol{\mu g} / \text { plate })\end{array}$ & $\begin{array}{c}\text { Revertants/plate } \\
\text {-S9 }\end{array}$ \\
\hline $\begin{array}{l}\text { Solvent control }(100 \mu l \text { distilled water }) \\
\text { Chloroquine }\end{array}$ & $155.00 \pm 12.355$ \\
10 & \\
100 & $200.25 \pm 28.35$ \\
500 & $285.75 \pm 7.27 *$ \\
1000 & $274.50 \pm 29.01 *$ \\
5000 & $293.25 \pm 28.70^{*}$ \\
& $109.75 \pm 8.99$
\end{tabular}

Positive control

SA $(1.5 \mu \mathrm{g} / \mathrm{plate}) \quad 1139.5 \pm 70.33$ 
Table 2: Number of revertants induced by chloroquine in salmonella plate incorporation test using TA 98 strain

\begin{tabular}{llll}
\hline Chemicals & & Revertants/plate \\
$(\mu \mathrm{g} /$ plate $)$ & $-\mathrm{S9}$ & $+\mathrm{S} 9$ & \\
\hline
\end{tabular}

Solvent control

(100 $\mu$ l distilled water)

$44.75 \pm 3.77$

$43.25 \pm 6.70$

$51.75 \pm 8.50$

$58.00 \pm 8.86$

$64.00 \pm 8.28$

$23.50 \pm 6.25$

5000

Positive control

NPD $(20 \mu \mathrm{g} /$ plate $)$

$1272.25 \pm 168.64$

2-AF $(10 \mu \mathrm{g} /$ plate $)$

$2317 \pm 236.63$

- S9 = without metabolic activation.

$+S 9=$ with metabolic activation.

All data represented here are Mean $\pm S D$ of four plates. Results for each concentration were compared with the solvent treated control by $D$ unnet's Multiple comparison test. NPD=4-nitro-o-phenylenediamine, $2 A F=2$-aminofluorene.

\section{CONCLUSION:}

The results of the mutagenicity assay indicate that chloroquine is a weak mutagen in Salmonella strain TA100. CHQ showed a very weak mutagenic effect in the absence of S9 mix in strain TA100. But this compound didn't show any mutagenic effect on TA98 strain both in presence or absence of S9 mix. This observation suggests that metabolic products of CHQ might not play a significant role in induction of mutation. CHQ is rapidly and almost completely absorbed from the GI tract and localized in tissues especially in kidney, liver, lung, spleen and in skin. From the tissue this drug is slowly excreted and the drug-metabolites may be present in the tissue for months or even years. Moreover the recommended dose for CHQ is relatively high (about $300 \mathrm{mg}$ per tablet). So, exposure of $\mathrm{CHQ}$ in human tissue for prolonged time

\section{REFRENCES:}

1 Ames,B.N., Durston,W.E., Yamasaki,E. and Lee,F.D. Carcinogens are mutagens: a simple test system combining liver homogenates for activation and bacteria for detection, Proc. Natl. Acad. Sci. USA, 1973, 70, 2081-2285.

2 Boelaert,J.R., Piette J and Sperber, KThe potential place of chloroquine in the treatment of HIV-1-infected patients. J Clin Virol., 2001, 20,137-140.

3 Bruce-Chwatt,L.J. Chemotherapy of malaria, Revised $2^{\text {nd }}$ Edn. WHO Monograph Series no. 27, WHO, Geneva, Switzerland, 1986, pp. 61-64.

4 Dunnet,C.W. A multiple comparison procedure for comparing several treatments with the control. J. Am. Statist. Assoc., 1955, 50, 1096-1121.

5 Garner,R.C., Miller,E.C. and Miller,J.A. Liver microsomal metabolism of aflatoxin $\mathrm{B} 1$ to a reactive derivative toxic to Salmonella typhimurium TA 1530. Cancer Res., 1972, 32, 20582066.

6 Levin,D.E., Hollstein,M.C., Christman,M.F., Schwiers,E.A. and Ames,B.N. A new Salmonella Strains (TA102) with A:T base pair at the site of mutation detects oxidative mutagens. Proc. Natl. Acad. Sci., (1982) 79, 7445-7449. Linquist,N.G. Accumulation of drugs on melanin. Acta Radiol, 325 (suppl.), 1973, 1-92. period could increase the risk of mutation in tissue cells though the compound is found to be weakly mutagenic by Ames test. Our results also indicate chloroquine might be able to induce base pair mutation than that of frame shift mutation. Taking together these findings indicate that it is weak mutagenic compound and the use of this drug should monitor properly and excessive use of this drug should be avoided.

\section{ACKNOWLEDGEMENT:}

The author is grateful to Dr. Pranita kashyap Principal of the shri rawatpura institute of pharmacy we thankful for permitting this research work. The author's acknowledges the staff members and friends of PG department of pharmacy for their kind co-operation for complete this successful research work.

7 Maron,D.M. and Ames,B.N. Revised methods for the Salmonella mutagenecity test. Mutation Research, 1983, 113, 173-215.

8 Martindale,H. Martindale the extra pharmacopoeia. J.E.F.Reynolds(ed.). The Pharmaceutical press, London, UK, 1996, p. 464.

9 McChesney,E.W. and McAnliff,J.P. Laboratory studies of the four aminoquinoline antimalarials. I. Some biochemical characteristics of chloroquine, hydrochloroquine and SN-7718. Antibiot. Chemother, 1961, 11, 800-810.

10 Sharma,A. and Rawat,A.K. Toxicological consequences of chloroquine and ethanol on the developing foetus. Pharmacol Biochem. Behav., 1989, 34, 77-82.

11 Tripathi,K.D. Essentials of medical pharmacology $5^{\text {th }}$ edition, , by Jaypee Brothers Medical Publisher Ltd, 2003, 739, 740.

12 Wichard,L.P, Waashington,M.E. and Holbrook,D.J.,Jr. The inhibition in vitro of bacterial DNA polymerase and RNA polymerase by antimalarial 8 -aminoquinolines and by chloroquine. Biochem. Biophys. Acta, 1972, 287, 52-67.

13 Yielding,K.L., Yielding,L. and Gaudin,D. Inhibition by chloroquine of UV repair in E.coli B. Proc Soc Exp. Biol. Med., 1970, 133, 99-101. 